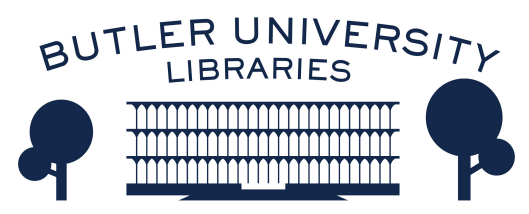

Journal of Hindu-Christian Studies

\title{
Is God Good? Aquinas, Śamkara, Abhinavagupta, Balinese Śaivism, and the Problematics of the Argument from Evil
}

Lance E. Nelson

University of San Diego

Follow this and additional works at: https://digitalcommons.butler.edu/jhcs

Part of the Catholic Studies Commons, Christianity Commons, Hindu Studies Commons, and the Religious Thought, Theology and Philosophy of Religion Commons

\section{Recommended Citation}

Nelson, Lance E. (2016) "Is God Good? Aquinas, Śamkara, Abhinavagupta, Balinese Śaivism, and the Problematics of the Argument from Evil," Journal of Hindu-Christian Studies: Vol. 29, Article 3.

Available at: https://doi.org/10.7825/2164-6279.1626

The Journal of Hindu-Christian Studies is a publication of the Society for Hindu-Christian Studies. The digital version is made available by Digital Commons @ Butler University. For questions about the Journal or the Society, please contact cbauman@butler.edu. For more information about Digital Commons @ Butler University, please contact digitalscholarship@butler.edu. 


\section{Is God Good? Aquinas, Śaṃkara, Abhinavagupta, Balinese Śaivism, and the Problematics of the Argument from Evil \\ Lance E. Nelson \\ University of San Diego}

I have long thought that comparative theology could make important contributions to the perennial discussion of "the problem of evil," or more specifically in the present case, the modern "argument from evil." As an argument against the existence of God, the latter was first forcefully articulated by philosophers of the Enlightenment. ${ }^{2}$ As is well known, however, its importance continues to the present day. It has long been considered "the most powerful objection to traditional theism."

The problem of evil-as opposed to the argument from evil-is an ancient one, but it was not initially formulated as an argument in support of atheism. God's existence was taken for granted, and on that basis thinkers like Augustine engaged an serious intellectual struggle with deep questions about the divine raised by the presence of evil in the world: the unicity of God, the knowability of God, the possibility of Divine providence. ${ }^{4}$ The atheist argument from evil-especially as expounded of late by the New Atheists--tends to reduce this history to a caricature.
The question of God's goodness is what I want to focus on in this paper. What exactly "good" means in this context is often extraordinarily ambiguous. Nevertheless, the assumed meaning nowadays seems to be that God is morally good. Richard Dawkins, in his book The God Delusion, remarks, "It is childishly easy to overcome the problem of evil. Simply postulate a nasty god." Must the God of monotheism therefore necessarily be a "nice" God, as Dawkins seems to imply? ${ }^{6}$ One problem with this formulation is that it takes for granted that God is a moral agent that can be judged, and found wanting, by the same sort of external standards that we apply in judging other human beings. Is this uniformly the case in the Christian tradition? What about thinkers and mythmakers in other religious traditions?

In exploring a small aspect of this question here, I will be working with Aquinas, Śamkara and the Advaita tradition, and Abhinavagupta and the nondual śaivism of Kashmir. I will also refer briefly to Balinese Hinduism, an interesting expression of pre-Abhinava Śaivism.

Lance E. Nelson is professor of theology and religious studies at the University of San Diego, where he teaches courses in world religions, Asian religious traditions, and religion and ecology. He received his Ph.D. in religious studies from McMaster University. Nelson's research focuses on medieval Hindu theology, the relation of religion and environmental activism, and Hindu-Christian dialogue. His writings on aspects of South Asian religious and philosophical thought have appeared in books, reference works, and scholarly journals in the United States and India. He edited Purifying the Earthly Body of God: Religion and Ecology in Hindu India. Nelson is a former president of the Society of Hindu-Christian Studies.

Journal of Hindu-Christian Studies 29 (2016):4-12 
Aquinas-though he has a lot to day about God, good, and evil-does not seriously engage the atheist argument from evil. Śamkara was aware of the challenge of atheism, and he does offer a theodicy, but it is a preliminary one, not representing his final view. Abhinavagupta and his tradition, in terms of theological discourse, have scarcely anything to say on evil as it might problematize conceptions of God, for it seems to them not a problem, though the Śaiva mythic corpus speaks in its own way. For Hindus in Bali, the idea that God is good is taken to be simplistic.

To be clear, my concern here is not any solution to the problem of evil as such, but rather the prior question of God's goodness. In particular, I'm interested in whether or not God is properly considered to be morally good in a way that the modern argument from evil assumes that God, if God exists, must necessarily be. ${ }^{7}$ My basic proposition is that, for the writers and ways of thought I'm looking at, God is precisely not morally good, in the sense that any moral standards we use in judging our fellow human beings are not properly applied to God. It should be, I hope, obvious that this does not mean that these traditions think of God as immoral; for these writers God is-in a wordtransmoral.

\section{Aquinas}

As it happens, Aquinas offers what Hickson suggests is an early prototype of the argument from evil. ${ }^{8}$ Prior to this occurrence, Hickson can identify no discussion of evil aimed directly at disproving the existence of God (as opposed to provoking reflection on the unity or knowability of God or gods, or divine providence, or such questions). But Hickson is not at all sure that Aquinas took this argument seriously. He thinks, rather, that it was included as a prima facie view, according to the Aristotelian-Scholastic formula for such disputations, which required an initial statement of objection. ${ }^{9}$ In any event, here it is:

It seems that there is no God. For if one of two contraries were infinite, the other would be completely destroyed. But by the word 'God' we understand a certain infinite good. So, if God existed, nobody would ever encounter evil. But we do encounter evil in the world. So, God does not exist. (Summa Theologiae 1a.2.3 $)^{10}$

We do not have space to dwell on this example here. Neither, it seems, did Aquinas. As Hickson points out, Aquinas dispatched it in two sentences. But let us note in passing that this is a metaphysical, not a moral argument: there cannot be room for two infinite realities that are assumed to be contraries. What it specifically does not offer as a premise is the supposed moral goodness of God.

I would suggest that one important reason for this is that while Aquinas, with the rest of the Christian tradition, certainly thinks of God as good, he does not define that goodness in moral terms. Thus we read:

The goodness of something consists in its being desirable. Hence Aristotle's dictum that 'good is what everything desires'. But desirability evidently follows upon perfection, for things always desire their perfection. (Summa Theologiae Ia.5.1) $)^{11}$

So goodness is defined in terms of desirability and perfection. On that basis, Aquinas proceeds to argue for (1) the goodness of God, (2) for God as the supreme good, and (3) that only God is essentially good-but none of 
this in terms of God's morality. The discussion, as Stump characterizes it, is meta-ethical. ${ }^{12}$

God is certainly the cause of moral goodness in his creatures, but he is not himself a being that is possessed of moral virtues as humans are and that humans can understand. Neither is God subject to external moral obligations. As Brian Davies argues, Aquinas would consider any discussion of the "moral integrity" of God to be seriously misplaced. ${ }^{13}$ Aquinas is certainly aware that scripture and tradition have used words like "just," "truthful," "loving," "merciful" and, yes, "good" in reference to God. ${ }^{14}$ As is well known, however, Aquinas believes such attributions are analogical. He does not take them to mean that God possesses these qualities in anything close to the way in which humans do.

While, like Augustine, Aquinas had a good deal to say about God and evil, he had, as Davies points out forcefully, pretty much nothing to say on "what contemporary philosophers have come to call the problem of evil." ${ }^{15}$ It would not have occurred to him that God's goodness would be a matter of adjudication in terms of standards of morality applicable to human beings. Aquinas scholar Herbert McCabe puts it dramatically: "It is blasphemous nonsense to say that God is wicked, but it is equally inappropriate to say that he is morally good.... Moral good and evil belong to rational beings that achieve or fail to achieve perfection." ${ }^{" 16}$

\section{Śamkara and the Advaita Tradition}

In querying the goodness of Brahman, the ultimate reality in Advaita Vedānta, the first word that comes to mind is sat and its cognates, sattā and satya. These terms are often used to characterize or define Brahman. Sat in some contexts can mean "good." More commonly, certainly in Advaita discourse, it would properly be translated "truth," "reality," or simply "existence" or "being," in a purely ontological sense. ${ }^{17}$

Śamkara's definition of sat is quite simple: it is that which does not change (na vyabhicarati). ${ }^{18}$ Alternately, in the standard formulation of the later tradition, sat is defined as that which is never sublated by some higher knowledge in past, present, or future (tri-kāla-abhādya). I am not aware of Śamkara or his followers using sat in the sense of "goodness"-certainly not "moral goodness"-in relation to Brahman. Nor, for that matter, am I aware of any passages in the Upaniṣads where sat could be construed in this way in relation to Brahman. When paired, sat and asat must invariably be translated as being and nonbeing; satya is contrasted with anrta, as "truth and untruth." The concern is predominantly ontological and epistemological, albeit within a wider axiological and soteriological framework.

The word satya figures in the famous "definition" of Brahman found at Taittiriya Upanișad 2.1.1: satyam jnanam anantam brahma ("Brahman is real, knowledge, infinite"). Śamkara glosses satyam as "not changing," so that the verse comes out, through lakșanārtha (proximate secondary predication), as a bit of negative theology, "Brahman is what is not changing, not unreal, not unconscious, not limited." ${ }^{19}$ This negative theology, of course, finds its primary scriptural justification at Brhadāranyaka Upanișad 2.3.6, "This Self is spoken of as, 'Not thus, not thus' (neti neti)." For Samkara, this legitimates the ruthless discarding of limiting attributions (upādhi) in thinking about Brahman.

There are any number of passages that point to Brahman as transcending all distinctions 
( $d v a n d v a \bar{t} t \bar{t} t a)$, including what in English might be called the morally good and bad. Brahman, the Self, or the liberated sage (which are equivalent) are said in the Upanișads to be beyond both morality (dharma) and immorality (adharma), the desirable (priya) and the undesirable (apriya), good deeds (sukrta) and bad (duṣkrta), merit (punya) and sin (pāpa). ${ }^{20}$ Dramatically, Bṛadāranyaka Upanișad 4.3.22 declares: "There, a thief is not a thief, the murderer of a Brahmin is not a murderer of a Brahmin." Given that Brahminicide is arguably the most heinous crime in this particular universe of meaning, this is a powerful statement indeed.

In short, it would be hard to support any claim as to the moral goodness, or otherwise, of Brahman in classical Advaita. ${ }^{21}$ It seems clear that for this tradition Brahman is, as has often been said, "beyond good and evil." 22

Nevertheless, there are several passages dealing with theodicy in the Brahmasütra. In commenting on one of these Samkara is forced to defend the goodness of Brahman, indeed the moral goodness of Brahman as a moral agent. What are we to make of this?

Brahmasūtra 2.1.34 famously raises the question of whether Brahman, if regarded as the cause of the world, might be guilty of partiality (vaisamya) or even cruelty (nairghrnya) because of the different experiences and the suffering of his creatures. Samkara rises to the defense of God in the face of his objector's accusation that the Lord (iśvara) has created an unjust world (vișamām srșțim). "Owing to infliction of misery and destruction on all creatures," Śamkara's pūrvapakșin, or objector, charges, "the Lord will be open to the charge of extreme cruelty, abhorred even by the wicked." ${ }^{23}$ Here, it is clear that the Lord is being judged by external moral standards, ordinary human standards, as one would judge another human person. Śamkara accepts these terms, jumps into the fray, and defends the Lord. God, he says, cannot be accused of partiality or injustice because he is simply allotting to individuals the experiences they have earned by their karma. ${ }^{24}$

It is significant, however, that in an earlier passage, commenting on Brahmasūtra 2.1.21-22, Śamkara had already taken the argument in quite a different direction. There, he defends Brahman against the charge of failing to do what is good, not with the argument that the divine allocates experience on the basis of individuals' karma, but on the basis that Brahman does not really do anything at all: "The defects of not doing what is beneficial and so on cannot apply, because [for Brahman] there is nothing beneficial (hita) to be done nor harmful (ahita) to be avoided, since Brahman is eternally liberated by nature." Samkara makes clear that in this context he is talking from the paramārtika viewpoint, the perspective of absolute truth, in which the "creatorhood of Brahman" (brahmanas srastrtrtvam) has been "sublated by right knowledge," along with all "dualistic dealings, brought about by false ignorance." He continues: "Then, in that state, where can creation come from, and from where such defects as the failure to do that which is beneficial?" In short, he is saying that the supreme, nirguna Brahman is not accountable to any human standards, that indeed, Brahman, in itself, is neither a creator nor an agent of any action. From this point of view, the problem of unjust suffering in the world is easily solved: "From the absolute perspective," Śamkara writes, "saṃsāra does not exist" (saṃsāro na tu paramārthato 'sti). ${ }^{25}$

My conclusion: Śamkara is willing to champion the moral goodness of Brahman, or 
Íśvara, at a provisional-could we say analogical?-level of discourse, pertaining to the apara (lower) or saguna (qualified) Brahman. However, he would emphatically deny any conceptualization of moral goodness (or depravity) in relation to the supreme or para Brahman.

\section{Abhinavagupta and Kashmir Śaivism}

The Śaiva nondualism of Kashmir, as articulated most prominently by the great polymath Abhinavagupta, is a different sort of nondualism than Śamkara's Advaita. It could be called a nondualism by inclusion, since the world is celebrated as contained within the Divine, rather than a nondualism by exclusion, which achieves unity by dismissing the world. (Recall Śamkara's assertion, just above, of the ultimate non-existence of samsāra.) This could be termed a cosmic monism, as opposed to the classical Advaitin's acosmic monism. For Abhinava, the concept of a static, completely transcendent absolute contradicts the glorious independence (svātantrya) of the Lord to manifest at will a world that is not different from himself as, to use an analogy commonly employed in the tradition, images are not different from the mirror in which they appear. The Kashmir Śaiva adept correspondingly exults in her or his complete identity with God.

While concern is expressed-sometimes in quite dramatic terms-that the "secrets" of Śaiva teaching are not be revealed to those who are sinful (pāpa) or devoid of morality (dharmahina), ${ }^{26}$ those teachings, especially the secret ones, are unabashedly transmoral-and in some cases famously transgressive. If discussion of conventional ethical concerns is infrequent in Śamkara, it is even more difficult to find in Abhinavagupta's Śaivism. Indeed-as is well known-those adhering to ordinary morality are compared to "sheep" (paśu), ${ }^{27}$ in contrast with the spiritual elect, who are termed heroes (vira).

This is a complex tradition with multiple streams. One place of entrée is the prominent identification in Kashmir Śaivism of Paramaśiva, the supreme Śiva, as Bhairava, the "Frightful" or "Horrific." Abhinavagupta is regarded by tradition as an incarnation of Bhairava, and he is said to have departed from this world by entering into the Bhairava-guhā, "Bhairava's cave," not far from Srinagar, reciting the Bhairava Stava, a hymn (said to be his own composition) to the Deity in that form. ${ }^{29}$ An important conceptualization of liberation in this tradition is as bhairavaikātmya, "identity with Bhairava." 30

Now, prior to and to a real extent even after this Deity's adoption by Kashmir Śaiva Brahmins as a primary symbol of the ultimate, Bhairava was a terrifying God, associated with "the ascetic cremation-ground culture of heterodox and transgressive groups who sought power through control of and possession by hordes of frightening goddesses." ${ }^{31}$ Bhairava encompasses with his horrific, fanged appearance and associations the religion of the tantric vira, the hero who laughs at the pain and suffering of this world, seeing it as a product of ignorance. Suffering can be "devoured," or transformed by the power of supreme consciousness, with which the adept has identified. In his "Hymns in Imitation of Bhairava" (Bhairavānukaranastava), Abhinava's disciple Kṣemarāja praises Bhairava thus: "Lord! By wearing bones and the rosary made of hands and heads, and shining with the human blood, you instruct that the world is pure because it is of the nature of Brahman." ${ }^{32}$

As is well-known, this attitude toward the world was ritualized in the secret, transgressive 
rites described in Abhinava's Tantrāloka 29 and elsewhere. This approach aims at a consciousness "free of the contraction of laws, untouched by injunction or prohibition." ${ }^{33}$ In the end, it seeks what Sanderson has called a "mystic vision of fearless omnipotence." ${ }^{34}$ The practitioner identifies with Svacchanda Bhairava, the "Lord of the viras" (vira-nāyaka), the God who "devours everything" (sarvabhaksa). ${ }^{35}$

God's responsibility for the joy and suffering of creatures is not here avoided or denied; rather, it is celebrated. Bhairava is described in the Bahurūpagarbha Stotra, a section of the Svacchanda Tantra, as the "bestower of the experience of the terrifying samsāra" (ghorasamsāra-sambhoga-dāyine). He is the one who "bestows exceedingly terrible experiences in samsāra" (ghora-ghora-samsāra-dayine). ${ }^{36}$ The Stavacintammani declares that God's power (sāmarthya) is sufficient to allot worldly experiences and liberation to individuals without dependence on any external factor whatsoever (ananyāpekșa). ${ }^{37}$ Doniger's observation that "in Hinduism, evil (like good) is an integral part of God and stems from him"38 certainly applies to nondual Saivism.

\section{Śaivism in Bali}

In exploring some examples of religious outlooks that do not insist on the moral goodness of the Supreme Being, it is worth a short excursus on the Hinduism of Bali. There, as earlier in Java, a pre-Abhinavagupta form of Saivism took root and, though today under multiple threats political and otherwise, still flourishes, in ritual expressions especially, but also in secret texts, the lontars, preserved by village Brahmins. ${ }^{39}$
In a thought-provoking article entitled "Is God Evil?" the anthropologist Mark Hobart describes a conversation with Balinese informants:

Late one evening after a long discussion with a group of villagers, in which they commented on how many contradictions and inconsistencies their beliefs seemed to contain, I remarked that we too had our puzzles. In Christianity there was a paradox that, if God were good, omnipotent and omniscient, how could evil exist? To my surprise I was met with hoots of laughter. White people seemed so clever. How could they find difficult what was so obvious, even to simple villagers who could not read or write? One of them explained the matter to me, to mutters of agreement from the others. Of course God-in Bali Sang Hyang Widi, the highest, all-embracing Divinitywas bad (kaon). How else could there be bad in the world? ${ }^{40}$

The idea that the Deity can manifest in terrible forms is of course well attested in India itself. I might venture to say, however, based on my own informal experience in both India and Indonesia, that the Balinese on the whole remain more readily disposed to embrace such conceptions than contemporary Hindus. It is well-known in Balinese lore that God has a wrathful (pemurtian) aspect. ${ }^{41}$ The ambivalent nature of God in Bali has been explored in several interesting articles by Michelle Stephen, who undertook a study of myths of Śiva and Umā recorded in Balinese manuscripts. She concluded that these texts "revealed nothing less than that all destructive and dangerous forces in the world originate from the divine pair themselves, and that the aim of human 
ritual is primarily to cause these destructive forces to return to their original benign condition." ${ }^{42}$

\section{Conclusion}

In these remarks, I have not intended to address theodicy or propose any new "solutions" that might save anyone's faith from the atheists' argument from evil. Nevertheless, I hope what I have said will make a modest contribution to the discussion by raising a particular, limited question regarding that argument. If proponents of atheism, whether new or old, think that they have dealt religion a fatal blow using an argument that assumes that theists universally suppose that God is (morally) good, they are ignoring the wider evidence. If Notes

${ }^{1}$ Existing studies that I have found particularly helpful include: Malcolm David Eckel and Bradley L Herling, eds., Deliver Us from Evil (London; New York: Continuum, 2008); David J. Parkin, ed., The Anthropology of Evil (Oxford; New York: B. Blackwell, 1985).

${ }^{2}$ Marilyn McCord Adams and Robert Merrihew Adams, eds., The Problem of Evil (Oxford; New York: Oxford University Press, 1990), 3; Michael W. Hickson, "A Brief History of Problems of Evil," in The Blackwell Companion to the Problem of Evil, ed. Justin P. McBrayer and Daniel Howard-Snyder (Chichester, England: Wiley-Blackwell, 2013), 14. I am indebted to Hickson for his articulation of the distinction between the problem of evil and the argument from evil. Hickson (6-7) notes that, perhaps based on references in David Hume to "Epicurus' old questions," that the latter has been understood to be the originator of atheist argument from evil. Hickson points out, however, that (1) no text from Epicurus has been found to support this, and that (2) Epicurus believed in God, so that, if this line of argument did come from him, it is likely that it had "like Plato's believers, on the other hand, feel their faith threatened by such arguments, it may be that a broader conception of God's goodness is called for. As McCabe suggests, there is always a chance, "We may find, as Job did, that it was our own view of God that was infantile, [and thus] we may in fact come to a deeper understanding of the mystery of God." ${ }^{43}$

I have found the distinction between the atheist argument from evil and the reflectiveor aporetic ${ }^{44}$ - problem of evil to be most helpful.

The latter seems not so much a threat to faith as a question for contemplative struggle, at least to the extent that it focuses the mind on the mysteries of life and God.

even older questions, antiprovidential, not atheistic intent."

${ }^{3}$ Richard G. Swinburne, "Evil, the Problem of," ed. Ted Honderich, The Oxford Companion to Philosophy (Oxford: Oxford University Press, 2005), 274.

${ }^{4}$ Hickson, "A Brief History of Problems of Evil," 3-4. http://dx.doi.org/ 10.1002/9781118608005.ch1

${ }^{5}$ Richard Dawkins, The God Delusion (New York: Houghton Mifflin, 2006), 135.

${ }^{6}$ Paul Tillich observes: "The holy has become the morally good and the logically true. It has ceased to be the holy in the genuine sense of the word.... One could say that the holy originally lies below the alternative of the good and the evil; that it is both divine and demonic; that with the reduction of the demonic possibility the holy itself becomes transformed in its meaning; that it becomes rational and identical with the true and the good; and that its genuine meaning must be rediscovered" (Dynamics of Faith [New York: Harper Collins, 2011]),17.

${ }^{7}$ There is of course a related concern, important in this polarized day and age: the potential moral consequences of the belief that the God I worship is morally perfect--and in ways that are readily 
understandable to me. But this must remain beyond the scope of the present discussion.

${ }^{8}$ Hickson, "A Brief History of Problems of Evil,"

9-10. http://dx.doi.org/ 10.1002/9781118608005.ch1

${ }^{9} \mathrm{Ibid} ., 10$. There is of course a parallel in Sanskrit scholasticism, where arguments must include the pürvapakșa, the deliberately constructed "opponent's view."

${ }^{10}$ Thomas Aquinas, Summa Theologiae: Questions on God, ed. Brian Leftow and Brian Davies, Cambridge Texts in the History of Philosophy (Cambridge; New York: Cambridge University Press, 2006), 24.

${ }^{11}$ Ibid., 52.

${ }^{12}$ Eleonore Stump, Aquinas (London: Routledge, 2003), 90.

${ }^{13}$ Brian Davies, The Reality of God and the Problem of Evil (London; New York: Continuum, 2006), 97, 1045.

14 "Why do you call me good? No one is good but God alone," Lk. 18:19; Mk. 10:18 (NRSV).

${ }^{15}$ Brian Davies, Thomas Aquinas on God and Evil (Oxford; New York: Oxford University Press, 2011), 6.

${ }^{16}$ Herbert McCabe, God and Evil in the Theology of St Thomas Aquinas (New York: Continuum, 2010), 106.

${ }^{17}$ As an aside, one could note that Aquinas, following a long established tradition going back to Platonic thought, makes a close identification of goodness and being. See Scott Charles MacDonald, ed., Being and Goodness: The Concept of the Good in Metaphysics and Philosophical Theology (Ithaca, N.Y: Cornell University Press, 1991).

${ }^{18}$ Commentaries on Bhagavadgita $(\mathrm{BhG}) 2.16$ and Taittirìya Upanișad 2.1.1.

${ }^{19}$ Jacqueline Suthren Hirst, Śaṃkara's Advaita Vedānta: A Way of Teaching (London; New York: RoutledgeCurzon, 2005), 145-49.

${ }^{20}$ Kațha 2.14; Chāndogya 8.12.1; Kauśitakī 1.4; Muṇdaka 3.1.3, Bṛhadāranyaka 4.3.22.

${ }^{21}$ Other Hindu theologians, such as Rāmānuja, as Shulman points out, took pains to "proclaim the radical goodness of God." David Shulman, "Divine Order and Divine Evil in the Tamil Tale of Rāma," The
Journal of Asian Studies 38, no. 4 (August 1979): 2. http://dx.doi.org/10.2307/2053906

${ }^{22}$ Eliot Deutsch, Advaita Vedānta: A Philosophical Reconstruction (Honolulu: East-West Center Press, 1969), 99-100; Bimal Krishna Matilal, The Logical Illumination of Indian Mysticism: An Inaugural Lecture Delivered before the University of Oxford on 5 May 1977 (Oxford: Clarendon Press, 1977), 26. Cf. the remarks of Paul Tillich cited above, note 6.

${ }^{23}$ Śaṃkara on Brahmasūtra 2.1.34. Swami Gambhirananda, trans., Brahma-Sūtra-Bhāṣya of Śrī Śankarācārya, 4th ed. (Calcutta: Advaita Ashrama, 1983), 362.

${ }^{24}$ See Francis X. Clooney, "Evil, Divine Omnipotence, and Human Freedom: Vedānta's Theology of Karma," The Journal of Religion 69, no. 4 (October 1, 1989): $530-48$. http://dx.doi.org/10.1086/488203

25 Śaṃkara on Brahmasūtra 2.1.22, my translations.

${ }^{26}$ Bahurūpagarbha Stotra (BRG) 38-40; Hemendra Nath Chakravarty, "Bahurūpagarbha Stotra: An Annotated Translation," in Samarasya: Studies in Indian Art, Philosophy, and Interreligious Dialogue: In Honour of Bettina Bäumer, ed. Sadananda Das and Ernst Fürlinger (New Delhi: D.K. Printworld, 2005).

${ }^{27}$ Abhinavagupta, Tantrāloka 29.99.

${ }^{28}$ David Gordon White, "Bhairava," in Brill's Encyclopedia of Hinduism, edited by Knut A. Jacobsen, Helene Basu, Angelika Malinar, and Vasudha Narayanan. Consulted online on 21 July 2016 http://dx.doi.org/10.1163/2212-

5019_beh_COM_1030080

${ }^{29}$ Kanti Chandra Pandey, Abhinavagupta: An Historical and Philosophical Study, 2d ed., The Chowkhamba Sanskrit Studies, v. 1 (Varanasi: Chowkhamba Sanskrit Series Office, 1963), 23-24, 72.

${ }^{30}$ Ibid., 686.

${ }^{31}$ Paul E. Muller-Ortega, "Becoming Bhairava: Meditative Vision in Abhinavagupta's ParātrīśikāLaghuvrtti," in The Roots of Tantra, ed. Katherine Anne Harper and Robert L. Brown (Albany: State University of New York Press, 2002), 213. 
12 Lance Nelson

32 Bhairavānukaranastava 35; Sthaneshwar

Timalsina, "Contemplating the Image of Bhairava: A Study of Kshemarāja's Bhairavānukaranastava," Journal of Indian Research 1, no. 1 (2013): 50.

${ }^{33}$ Jayaratha's commentary on the Tantrāloka of Abhinavagupta; quoted by Alexis Sanderson, "Purity and Power Among the Brahmans of Kashmir," in The Category of the Person: Anthropology, Philosophy, History, ed. Michael Carrithers, Steven Collins, and Steven Lukes (Cambridge University Press, 1985), 199.

${ }^{34}$ Sanderson, ibid., 201.

${ }^{35}$ BRG 1, 18; Chakravarty, "Bahurūpagarbha Stotra."

${ }^{36} \mathrm{BRG} 7,34$.

37 Bhațta Nārāyaṇa, Stavacintāmaṇi of Bhatța Nārāyaṇa with the Commentary by Kșemarāja, trans. Boris Marjanovic (Varanasi: Indica Books, 2011).

${ }^{38}$ Wendy Doniger, The Origins of Evil in Hindu Mythology (University of California Press, 1976), 139.

${ }^{39}$ Andrea Acri, "Text and Reality in the Study of Balinese Hinduism," The Journal of Hindu Studies 7, no.
2 (August 1, 2014): $137-45$. http://dx.doi.org/10.1093/jhs/hiu019

${ }^{40}$ Mark Hobart, "Is God Evil?," in The Anthropology of Evil, ed. David J. Parkin (Oxford; New York: B. Blackwell, 1985), 188. Cf. the remarks of Paul Tillich cited above, note 6 .

${ }^{41}$ Christian Hooykaas, "Pamurtian in Balinese Art," Indonesia, no. 12 (October 1, 1971): 1-20. http://dx.doi.org/10.2307/3350655

${ }^{42}$ Michele Stephen, "Returning to Original Form: A Central Dynamic in Balinese Ritual," Bijdragen Tot de Taal-, Land- En Volkenkunde 158, no. 1 (2002): 64. http://dx.doi.org/10.1163/22134379-90003787 See also Stephen's "Barong and Rangda in the Context of Balinese Religion," Review of Indonesian and Malaysian Affairs 35, no. 1 (2001): 137-93.

43 Herbert McCabe, God Matters (London: Bloomsbury, 2015), 25.

${ }^{44}$ Adams and Adams, The Problem of Evil, 2; Hickson, "A Brief History of Problems of Evil," 3. 